\title{
Spin-top-like encrustation of suprapubic cystostomy catheter: when proper counselling is all that it takes!
}

\author{
Ashish Sharma, ${ }^{1}$ Samarth Agarwal, ${ }^{1}$ Deepanshu Sharma, ${ }^{2}$ Abhinav Veerwal ${ }^{3}$
}

'Department of Urology, King George's Medical University, Lucknow, Uttar-Pradesh, India ${ }^{2}$ King George's Medical University, Lucknow, UttarPradesh, India

${ }^{3}$ BJ Medical College, Ahmedabad, Gujarat, India

\section{Correspondence to} Dr Samarth Agarwal, rebellite@gmail.com

Accepted 29 August 2018
Check for updates

\section{(c) BMJ Publishing Group} Limited 2018. No commercial re-use. See rights and permissions. Published by BMJ.

To cite: Sharma A,
Agarwal S, Sharma D, et al.
BMJ Case Rep Published
Online First: [please
include Day Month Year].
doi:10.1136/bcr-2018-
226726

\section{DESCRIPTION}

A 25 -year-old man from a rural background and suffering from psychiatric illness had complaints of acute urinary retention 1 year ago for which trocarguided suprapubic cystostomy (SPC) Foley catheter placement was done elsewhere after failed attempt of per-urethral catheterisation.

There was no history of haematuria, lithuria, catheterisation and endourological intervention in the past. On further eliciting the history, there was a retrograde urethrogram film taken 1 year back which revealed a short segment $(1.0 \mathrm{~cm})$ bulbar urethral stricture. He had undergone optical internal urethrotomy with Foley catheter placement (14F) under regional anaesthesia for his urethral stricture. Per-urethral catheter was removed after 7 days and he voided well with good urinary stream. He was sent back home and instructed to follow-up after 3 days for removal of SPC catheter and need of de-clamping SPC catheter in case of urinary retention again.

However, a thorough counselling about catheter's care and related complications was not done by concerned surgeon and he was lost to follow-up.

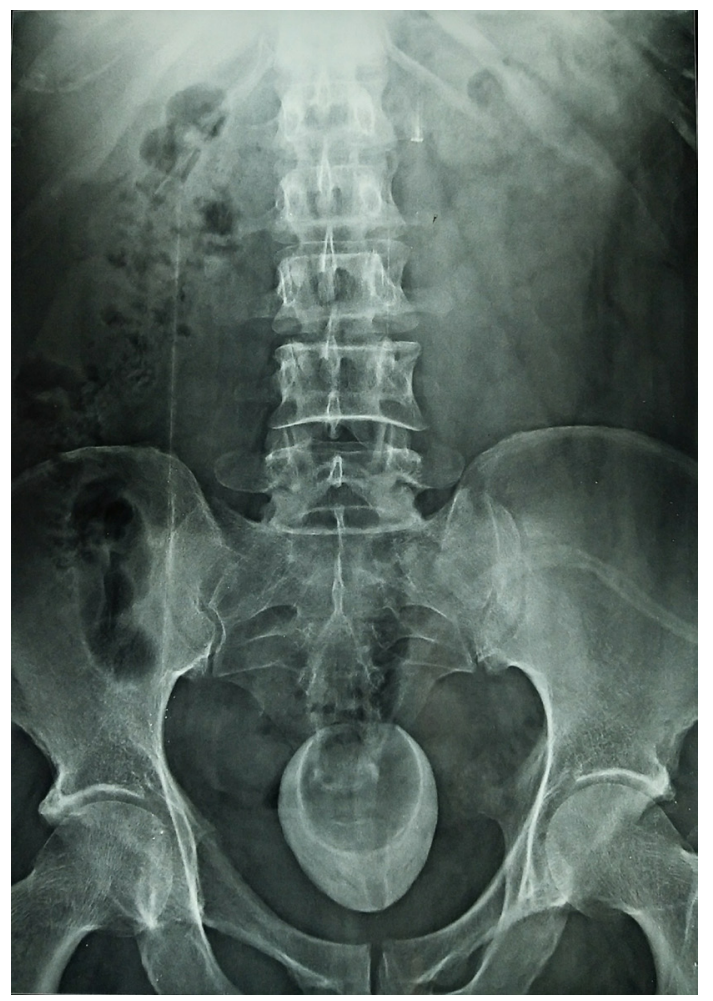

Figure 1 X-ray (kidney ureter bladder) showing huge 'spin-top'-like encrustation around balloon of suprapubic Foley catheter.

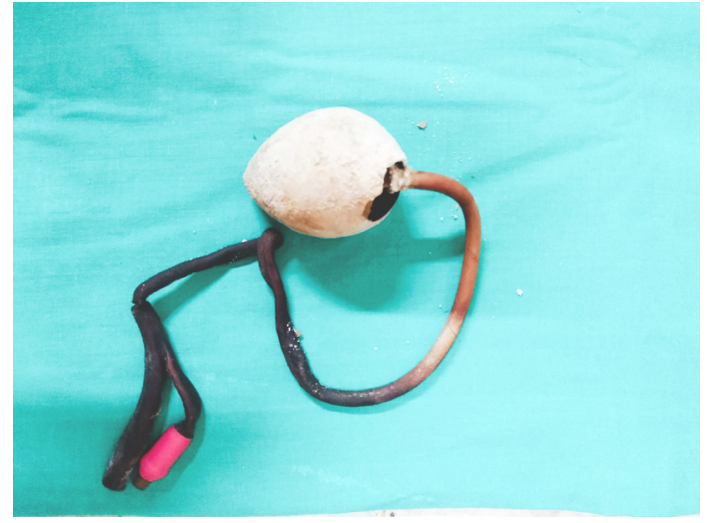

Figure 2 Encrusted suprapubic catheter balloon measuring $6 \times 4 \mathrm{~cm}$ and weighting $250 \mathrm{~g}$.

He now presented to us after 1 year with retained SPC with complaints of suprapubic discomfort, pyuria and fever with chills and rigour. When confronted about the presence of retained SPC catheter, he defended that since he was voiding well, he did not deem it necessary to be removed and neither was he explained the long-term consequences of a retained catheter.

Complete hemogram showed elevated leucocyte count of $18 \times 10^{9} / \mathrm{L}$ cells $/ \mathrm{mm}^{3}$ and normal renal function test. Urine culture revealed $E$. coli growth for which appropriate antibiotics were started.

Attempts at manual removal of SPC catheter by deflating the bulb proved unsuccessful.

Imaging was ordered and X-ray KUB (kidney ureter bladder) was performed, which revealed huge encrustation around balloon of suprapubic Foley catheter like a spin top as shown in figure 1.

Ultrasound KUB revealed a large hyperechoic shadow in the urinary bladder around the balloon of SPC Foley catheter with absence of bilateral hydronephrosis. After proper counselling and consent, he underwent suprapubic cystolithotomy with removal of large encrusted Foley catheter like a 'spin top' measuring $6 \times 4 \mathrm{~cm}$ in size and weighing $250 \mathrm{~g}$ as shown in figure 2.

At 6 months' follow-up, he was voiding well with healed suprapubic tract and without any urological complaints.

Suprapubic catheterisation is a commonly used alternative procedure to per-urethral catheterisation for short-term or long-term urinary drainage. ${ }^{1}$

Complication of prolonged indwelling urinary catheter may include urinary tract infections, catheter blockage, encrustations, pericatheter leakage, retained catheter and bladder spasms. ${ }^{12}$ Encrustations of urinary catheter are classified as intraluminal 
or extraluminal. It can impede deflation of the balloon and therefore cause a retained catheter. There are very few reported cases in literature of massive encrustation of retained Foley balloon.

The management options of the encrustations include extracorporeal shock wave lithotripsy, laser or pneumatic lithotripsy and cystolithotomy. ${ }^{34}$

In our case, we did not attempt extracorporeal shock wave lithotripsy, laser or pneumatic lithotripsy because the stone was large, hard and was associated with urethral stricture.

\section{Learning points}

- Indwelling urinary catheters should be avoided for longer duration. Prolonged indwelling urinary catheter may lead to infections, encrustations, bladder spasm, pericatheter leak, suprapubic vesicocutaneous fistula and retained catheter.

- If placed for a longer duration, proper follow-up is needed in such patients. Both short-term and long-term complications need to be addressed.

- Patient who are illiterate, come from a rural background or suffer from psychiatric illness are an important group who are quite incapacitated to take care of themselves. This invariably leads them getting neglected and causes their healthcare to be put under jeopardy. Hence, in such cases, it is of paramount importance to counsel the patient/ attendants regarding need for regular catheter change at 3-4 weekly intervals as it averts most of the catheter-related complications.

- Catheter-induced huge encrustation may be managed with extracorporeal or intracorporeal lithotripsy and cystolithotomy.
Whenever possible, indwelling urinary catheter should be avoided for long duration. Patients on SPC should be counselled properly about procedures undertaken, catheter care and related complications including bacteriuria, encrustations, leak and catheter retention. Most important is the need for regular catheter change at 3-4 weekly intervals, which averts most of these complications from taking place. This is particularly important for urological patients of urethral strictures and neurogenic bladder where catheters are usually placed for long periods.

Good catheter hygiene, sterile continuous closed drainage systems, and cleaning of catheter surface with soap and water are also necessary to minimise catheter-related complications including encrustations. Periodic balloon deflation and re-inflation to break overlying encrustations is advisable for prolonged indwelling catheter. ${ }^{2-4}$

Contributors AS: concept, design, supervision, processing, writing manuscript and critical analysis. SA: concept, design. DS: supervision, processing, writing manuscript and critical analysis. AV: writing manuscript and critical analysis.

Funding The authors have not declared a specific grant for this research from any funding agency in the public, commercial or not-for-profit sectors.

Competing interests None declared.

Patient consent Obtained.

Provenance and peer review Not commissioned; externally peer reviewed.

\section{REFERENCES}

1 Robinson J. Suprapubic catheterization: challenges in changing catheters. $\mathrm{Br}$ J Community Nurs 2005;10:461-4.

2 Getliffe K. How to manage encrustation and blockage of Foley catheters. Nurs Times 2003;99:59-61.

3 Canby-Hagino ED, Caballero RD, Harmon WJ. Intraluminal pneumatic lithotripsy for the removal of encrusted urinary catheters. J Urol 1999;162:2058-60.

4 Kojima Y, Yoshimura M, Hayashi Y, et al. Extracorporeal shock wave lithotripsy for vesical lithiasis. Urol Int 1998;61:35-8.

Copyright 2018 BMJ Publishing Group. All rights reserved. For permission to reuse any of this content visit

http://group.bmj.com/group/rights-licensing/permissions.

BMJ Case Report Fellows may re-use this article for personal use and teaching without any further permission.

Become a Fellow of BMJ Case Reports today and you can:

- Submit as many cases as you like

- Enjoy fast sympathetic peer review and rapid publication of accepted articles

- Access all the published articles

- Re-use any of the published material for personal use and teaching without further permission

For information on Institutional Fellowships contact consortiasales@bmjgroup.com

Visit casereports.bmj.com for more articles like this and to become a Fellow 